Article

\title{
Compositional Variation and Bioactivity of the Leaf Essential Oil of Montanoa guatemalensis from Monteverde, Costa Rica: A Preliminary Investigation
}

\author{
Victoria D. Flatt, Carlos R. Campos, Maria P. Kraemer, Brittany A. Bailey, Prabodh Satyal and \\ William N. Setzer * \\ Department of Chemistry, University of Alabama in Huntsville, Huntsville, AL 35899, USA; \\ E-Mails: flattvd@gmail.com (V.D.F.); campocr2013@gmail.com (C.R.C.); \\ maria.c.palazzo@vanderbilt.edu (M.P.K.); baileybr@umich.edu (B.A.B.); ps0013@uah.edu (P.S.) \\ * Author to whom correspondence should be addressed; E-Mail: wsetzer@chemistry.uah.edu; \\ Tel.: +1-256-824-6519; Fax: +1-256-824-6349.
}

Academic Editor: Satyajit D. Sarker

Received: 22 October 2015 / Accepted: 17 November 2015 / Published: 24 November 2015

\begin{abstract}
Background: Montanoa guatemalensis is a small to medium-sized tree in the Asteraceae that grows in Central America from Mexico south through Costa Rica. There have been no previous investigations on the essential oil of this tree. Methods: The leaf essential oils of M. guatemalensis were obtained from different individual trees growing in Monteverde, Costa Rica, in two different years, and were analyzed by gas chromatography_mass spectrometry. Results: The leaf oils from 2008 were rich in sesquiterpenoids, dominated by $\alpha$-selinene, $\beta$-selinene, and cyclocolorenone, with lesser amounts of the monoterpenes $\alpha$-pinene and limonene. In contrast, the samples from 2009 showed no $\alpha$ - or $\beta$-selinene, but large concentrations of trans-muurola-4(14),5-diene, $\beta$-cadinene, and cyclocolorenone, along with greater concentrations of $\alpha$-pinene and limonene. The leaf oils were screened for cytotoxic and antimicrobial activities and did show selective cytotoxic activity on MDA-MB-231 breast tumor cells. Conclusion: M. guatemalensis leaf oil, rich in cyclocolorenone, $\alpha$-selinene, and $\beta$-selinene, showed selective in vitro cytotoxic activity to MDA-MB-231 cells. The plant may be a good source of cyclocolorenone.
\end{abstract}


Keywords: essential oil composition; cyclocolorenone; selinene; muuroladiene; cadinene; limonene; pinene; cytotoxicity

\section{Introduction}

Montanoa guatemalensis B.L. Rob. \& Greenm. (Asteraceae), "tubú", is a small to medium tree $(3-15 \mathrm{~m})$ that is found in Central America from Mexico through Costa Rica. The leaves are around $13 \times 17 \mathrm{~cm}$ and have $2-4$ shallow lobes. The flowers have large heads ( $5 \mathrm{~cm}$ diameter) with white ray flowers (2.5 cm long) and orange inner disk flowers [1]. This tree has been planted as windbreaks in Monteverde [2]. Germacranolide sesquiterpenoids have been isolated from M. guatemalensis [3], but to our knowledge, the volatile composition of this tree has not been previously investigated. In this work, we present the leaf essential oil composition of M. guatemalensis.

\section{Experimental Section}

\subsection{Plant Material}

Leaves of Montanoa guatemalensis were collected from two different mature trees (tree A and tree B, flowering stage) on 3 May 2008, and two different mature trees (tree C and tree D, flowering stage) on 7 May 2009, from the property of Hotel El Bosque, Monteverde, Costa Rica (10.3059 N, $84.8144 \mathrm{~W}, 1380 \mathrm{~m}$ above sea level). The plant was identified by William Haber, and a voucher specimen (Haber 425) has been deposited in the herbarium of the Missouri Botanical Garden. The fresh leaves were chopped and hydrodistilled using a Likens-Nickerson apparatus with continuous extraction with $\mathrm{CHCl}_{3}$ to give the yellow essential oils (Table 1).

Table 1. Yields of leaf essential oils from Montanoa guatemalensis.

\begin{tabular}{cccc}
\hline Sample & Mass Fresh Leaves & Mass Essential Oil & Yield \\
\hline 2008 , tree A & $46.3 \mathrm{~g}$ & $188 \mathrm{mg}$ & $0.41 \%$ \\
2008 , tree B & $34.0 \mathrm{~g}$ & $160 \mathrm{mg}$ & $0.47 \%$ \\
2009 , tree C & $122.1 \mathrm{~g}$ & $525 \mathrm{mg}$ & $0.43 \%$ \\
2009 , tree D & $192.1 \mathrm{~g}$ & $791 \mathrm{mg}$ & $0.41 \%$ \\
\hline
\end{tabular}

\subsection{Gas Chromatographic-Mass Spectral Analysis}

A gas chromatographic-mass spectral analysis was performed on the essential oils of $M$. guatemalensis using an Agilent 6890 GC with Agilent 5973 mass selective detector (Santa Clara, CA, USA) (EIMS, electron energy $=70 \mathrm{eV}$, scan range $=45-400 \mathrm{amu}$, and scan rate $=3.99 \mathrm{scans} / \mathrm{s}$ ), and a fused silica capillary column (HP-5ms, $30 \mathrm{~m} \times 0.25 \mathrm{~mm}$ ) coated with $5 \%$ phenyl-polymethylsiloxane ( $0.25 \mathrm{~mm}$ phase thickness). The carrier gas was helium with a flow rate of $1 \mathrm{~mL} / \mathrm{min}$, and the injection temperature was $200{ }^{\circ} \mathrm{C}$. The oven temperature was programmed to initially hold for $10 \mathrm{~min}$ at $40^{\circ} \mathrm{C}$, then ramp to $200{ }^{\circ} \mathrm{C}$ at $3{ }^{\circ} \mathrm{C} / \mathrm{min}$ and finally to $220{ }^{\circ} \mathrm{C}$ at $2{ }^{\circ} \mathrm{C} / \mathrm{min}$. The interface temperature was $280{ }^{\circ} \mathrm{C}$. 
A $1 \%$ w/v solution of each sample in $\mathrm{CHCl}_{3}$ was prepared, and $1 \mu \mathrm{L}$ was injected using a splitless injection technique.

Identification of the oil components was based on their retention indices determined by reference to a homologous series of $n$-alkanes, and by comparison of their mass spectral fragmentation patterns with those available in commercial libraries [4,5] as well as our own in-house library [6]. The percentages of each component are reported as raw percentages based on total ion current without standardization. The chemical compositions of the M. guatemalensis leaf oils are summarized in Table 2.

Table 2. Chemical compositions of the leaf essential oils of Montanoa guatemalensis.

\begin{tabular}{|c|c|c|c|c|c|}
\hline \multirow{2}{*}{$\mathbf{R I}^{\mathbf{a}}$} & \multirow{2}{*}{ Compound } & \multicolumn{2}{|c|}{2008} & \multicolumn{2}{|c|}{2009} \\
\hline & & Tree A & Tree B & Tree C & Tree D \\
\hline 923 & Artemisia triene & 0.69 & 0.13 & - & - \\
\hline 939 & $\alpha$-Pinene & 3.18 & 3.78 & 6.91 & 8.56 \\
\hline 958 & Camphene & 0.76 & 0.68 & - & 2.18 \\
\hline 980 & Sabinene & 0.32 & 0.07 & - & - \\
\hline 982 & $\beta$-Pinene & 0.74 & 0.93 & 1.81 & 3.71 \\
\hline 990 & Myrcene & 0.12 & 0.12 & 0.10 & 0.27 \\
\hline 1007 & iso-Sylvestrene & 1.65 & 0.48 & - & 1.84 \\
\hline 1030 & Limonene & 8.25 & 8.05 & 21.31 & 12.15 \\
\hline 1040 & (Z)- $\beta$-Ocimene & $\operatorname{tr}^{\mathrm{b}}$ & $\operatorname{tr}$ & - & - \\
\hline 1051 & $(E)-\beta$-Ocimene & 1.42 & 0.96 & 2.42 & 1.72 \\
\hline 1063 & Artemisia ketone & - & - & 1.77 & - \\
\hline 1075 & cis-Linalool oxide (furanoid) & 0.52 & $\operatorname{tr}$ & - & - \\
\hline 1086 & Artemisia alcohol & 0.05 & $\operatorname{tr}$ & 1.67 & 0.67 \\
\hline 1106 & Linalool & - & - & 0.14 & - \\
\hline 1165 & Borneol & 0.53 & 0.08 & - & - \\
\hline 1178 & Artemisyl acetate & 0.82 & 0.92 & 9.79 & 1.20 \\
\hline 1282 & Bornyl acetate & 0.06 & $\operatorname{tr}$ & - & - \\
\hline 1340 & $\delta$-Elemene & 2.27 & 1.45 & 1.43 & 1.40 \\
\hline 1349 & $\alpha$-Cubebene & - & $\operatorname{tr}$ & - & - \\
\hline 1365 & $\alpha$-Ylangene & - & $\operatorname{tr}$ & - & - \\
\hline 1371 & Unidentified $^{\mathrm{c}}$ & 0.19 & - & 1.28 & - \\
\hline 1376 & $\alpha$-Copaene & 0.21 & 0.32 & - & 1.32 \\
\hline 1384 & $\alpha$-Bourbonene & - & $\operatorname{tr}$ & - & - \\
\hline 1391 & $\beta$-Elemene & 0.16 & 0.10 & - & - \\
\hline 1391 & $\beta$-Cubebene & - & 0.12 & 0.11 & 0.20 \\
\hline 1408 & $\alpha$-Gurjunene & 0.09 & - & - & - \\
\hline 1420 & (E)-Caryophyllene & 3.39 & 1.39 & 2.46 & 2.14 \\
\hline 1429 & $\beta$-Gurjunene (=Calarene) & 0.07 & 0.08 & - & - \\
\hline 1436 & $\gamma$-Elemene & 0.26 & 0.39 & 0.30 & 0.42 \\
\hline 1439 & $\alpha$-Guaiene & 0.07 & 0.10 & - & - \\
\hline 1444 & 6,9-Guaiadiene & 0.26 & 0.19 & 0.13 & 0.06 \\
\hline 1447 & 9-epi-(E)-Caryophyllene & $\operatorname{tr}$ & $\operatorname{tr}$ & - & - \\
\hline 1454 & $\alpha$-Humulene & 0.75 & 0.59 & 0.82 & 0.59 \\
\hline 1460 & allo-Aromadendrene & 0.26 & 0.12 & - & - \\
\hline 1493 & $\beta$-Selinene & 8.69 & 14.77 & - & - \\
\hline
\end{tabular}


Table 2. Cont.

\begin{tabular}{|c|c|c|c|c|c|}
\hline \multirow{2}{*}{$\mathbf{R I}^{\mathbf{a}}$} & \multirow{2}{*}{ Compound } & \multicolumn{2}{|c|}{2008} & \multicolumn{2}{|c|}{2009} \\
\hline & & Tree A & Tree B & Tree C & Tree D \\
\hline 1494 & trans-Muurola-4(14),5-diene & - & - & 9.49 & 16.81 \\
\hline 1500 & Bicyclogermacrene & 2.03 & 2.10 & 1.40 & 3.05 \\
\hline 1516 & $\alpha$-Selinene & 21.15 & 15.90 & - & - \\
\hline 1518 & $\beta$-Cadinene & - & 0.20 & 13.26 & 11.10 \\
\hline 1522 & $\delta$-Cadinene & 0.86 & 0.94 & - & 0.42 \\
\hline 1545 & Selina-3,7(11)-diene & 3.63 & 4.54 & 3.55 & 7.96 \\
\hline 1548 & $\gamma$-Vetivenene & 1.79 & 2.09 & - & - \\
\hline 1561 & Germacrene B & 3.49 & 4.20 & 1.98 & 2.48 \\
\hline 1570 & Palustrol & - & - & - & 0.72 \\
\hline 1582 & Zierone & 0.86 & 0.52 & 0.30 & - \\
\hline 1590 & Khusimone & 0.20 & 0.13 & 0.39 & 0.35 \\
\hline 1603 & Guaiol & - & - & - & 0.65 \\
\hline 1629 & Unidentified $^{\mathrm{d}}$ & 2.29 & 2.62 & 1.00 & 2.92 \\
\hline 1642 & Selina-3,11-dien-6 $\alpha$-ol & 0.36 & 0.33 & 0.14 & - \\
\hline 1653 & Atractylone & 0.70 & 0.56 & 0.47 & 0.63 \\
\hline 1667 & Unidentified $^{\mathrm{e}}$ & 0.79 & 0.55 & 0.14 & - \\
\hline 1688 & $\alpha$-Bisabolol & 0.50 & 0.19 & - & 0.07 \\
\hline 1718 & neo-Cyclocolorenone & 0.09 & $\operatorname{tr}$ & - & - \\
\hline 1743 & Cyclocolorenone & 23.82 & 27.54 & 14.49 & 15.61 \\
\hline 1762 & Methyl 3,9,11-guaiatrien-12-oate & 0.38 & 0.18 & 0.51 & - \\
\hline 1833 & iso-Cyclocolorenone & 0.17 & 0.06 & - & - \\
\hline 1950 & Geranyl- $\alpha$-terpinene & 0.13 & - & - & - \\
\hline 2006 & Geranyl-p-cymene & 0.17 & 0.34 & - & - \\
\hline- & Monoterpenoids & 19.40 & 16.53 & 45.92 & 32.31 \\
\hline- & Sesquiterpenoids & 79.77 & 82.27 & 53.64 & 68.90 \\
\hline- & Total Identified & 95.90 & 95.64 & 97.14 & 98.28 \\
\hline
\end{tabular}

${ }^{a} \mathrm{RI}=$ Retention Index determined in reference to a homologous series of $n$-alkanes on an HP-5ms column; b $\operatorname{tr}=$ "trace" $(<0.05 \%)$; c MS (EI, m/e): 170(5), 169(24), 136(16), 121(79), 107(37), 105(41), 93(100), 91(73), 85(90), 79(59), 77(49), 74(60), 57(94); d MS (EI, m/e): 204(33), 202(100), 187(71), 173(19), 161(21), 159(51), 145(53), 131(61), 119(36), 105(54), 93(55), 91(71), 79(43), 77(36); e MS (EI, m/e): 218(100), 203(23), 175(17), 159(30), 149(29), 133(28), 119(25), 108(40), 105(35), 95(51), 93(56), 91(51), 79(43), 77(34), 67(25), 53(19).

\subsection{Antibacterial Screening}

The M. guatemalensis leaf oils were screened for antibacterial activity against Bacillus cereus (American Type Culture Collection, Manassas, VA, USA, ATCC No. 14579), Staphylococcus aureus (ATCC No. 29213), and Escherichia coli (ATCC No. 10798). Minimum inhibitory concentrations (MICs) were determined using the microbroth dilution technique [7]. Dilutions of the crude extracts were prepared in cation-adjusted Mueller-Hinton broth (Fisher Scientific, Pittsburgh, PA, USA) (CAMHB) beginning with $50 \mu \mathrm{L}$ of $1 \% \mathrm{w} / \mathrm{w}$ solutions of crude extracts in dimethylsulfoxide (Sigma-Aldrich, St. Louis, MO, USA) (DMSO) plus $50 \mu$ L CAMHB. The extract solutions were serially diluted (1:1) in CAMHB in 96-well plates. Organisms at a concentration of approximately $1.5 \times 10^{8}$ colony-forming 
units $(\mathrm{CFU}) / \mathrm{mL}$ were added to each well. Plates were incubated at $37^{\circ} \mathrm{C}$ for $24 \mathrm{~h}$; the final minimum inhibitory concentration (MIC) was determined as the lowest concentration without turbidity. Geneticin ${ }^{\circledR}$ (Sigma-Aldrich, St. Louis, MO, USA) was used as a positive antibiotic control; DMSO was used as a negative control.

\subsection{Cytotoxicity Screening}

Human MDA-MB-231 breast adenocarcinoma cells (ATCC No. HTB-26) [8] were grown in an air environment at $37{ }^{\circ} \mathrm{C}$ in Leibovitz's L-15 medium (Fisher Scientific, Pittsburgh, PA, USA) with L-glutamine, supplemented with $10 \%$ fetal bovine serum, 100,000 units penicillin and $10.0 \mathrm{mg}$ streptomycin per liter of medium, and buffered with $30 \mathrm{mM}$ (4-(2-hydroxyethyl)-1-piperazineethanesulfonic acid ) (Hepes, Fisher Scientific, Pitsburgh, PA, USA), pH 7.35. Human Hs578T breast ductal carcinoma cells (ATCC No. HTB-129) [9] were grown in a 3\% $\mathrm{CO}_{2}$ environment at $37{ }^{\circ} \mathrm{C}$ in Dulbecco's Modified Eagle Medium (DMEM) (Fisher Scientific, Pittsburgh, PA, USA) with $4500 \mathrm{mg}$ glucose per liter of medium, supplemented with $10 \%$ fetal bovine serum, $10 \mu \mathrm{g}$ bovine insulin, 100,000 units penicillin and $10.0 \mathrm{mg}$ streptomycin per liter of medium, and buffered with $44 \mathrm{mM} \mathrm{NaHCO} 3, \mathrm{pH} 7.35$.

MDA-MB-231 cells were plated into 96-well cell culture plates, at $2.6 \times 10^{4}$ cells per well, and Hs578T cells at $1.0 \times 10^{5}$ cells per well. The volume in each well was $100 \mu \mathrm{L}$ for all cell types. After $48 \mathrm{~h}$, supernatant fluid was removed by suction and replaced with $100 \mu \mathrm{L}$ growth medium containing $1.0 \mu \mathrm{L}$ of DMSO solution of essential oils ( $1 \% w / w$ in DMSO), giving a final concentration of $100 \mu \mathrm{g} / \mathrm{mL}$ for each oil. Solutions were added to wells in four replicates. Medium controls and DMSO controls $(10 \mu \mathrm{L} \mathrm{DMSO} / \mathrm{mL})$ were used. Tingenone $(100 \mu \mathrm{g} / \mathrm{mL})$ was used as a positive control [10]. After the addition of compounds, plates were incubated for $48 \mathrm{~h}$ at $37^{\circ} \mathrm{C}$; medium was then removed by suction, and $100 \mu \mathrm{L}$ of fresh medium was added to each well. In order to establish percent kill rates, the 3-(4,5-dimethylthiazol-2-yl)-2,5-diphenyltetrazolium bromide (MTT, Sigma-Aldrich, St. Louis, MO, USA) assay for cell viability was carried out [11]. After colorimetric readings were recorded (using a Molecular Devices (Sunnyvale, CA, USA) SpectraMAX Plus microplate reader, $570 \mathrm{~nm}$ ), average absorbances, standard deviations, and percent kill ratios (\%killoil/\%killomso) were calculated. Cytotoxic activities of the essential oils are summarized in Table 3.

Table 3. Bioactivity screening of the leaf essential oils of Montanoa guatemalensis.

\begin{tabular}{cccccc}
\hline \multirow{2}{*}{ Essential Oil Sample } & \multicolumn{3}{c}{ Antibacterial (MIC, $\boldsymbol{\mu g} / \mathbf{m L})$} & \multicolumn{2}{c}{ Cytotoxicity (\% Kill at $\mathbf{1 0 0} \boldsymbol{\mu g} / \mathbf{m L})$} \\
\cline { 2 - 6 } & B. cereus & S. aureus & E. coli & MDA-MB-231 & Hs578T \\
\hline 2008, tree A & 313 & 1250 & 2500 & 100 & $6.5 \pm 8.8$ \\
2008, tree B & 625 & 1250 & 2500 & 100 & 0 \\
2009, tree C & 313 & 1250 & 2500 & $66.3 \pm 5.6$ & 0 \\
2009, tree D & 313 & 1250 & 2500 & $21.9 \pm 3.5$ & 0 \\
\hline
\end{tabular}

\section{Results and Discussion}

The leaves from two different mature trees were collected in 2008 and from two different trees in 2009. The leaves were hydrodistilled to give pale yellow essential oils $(0.41 \%-0.47 \%$ yield), which 
were analyzed by gas chromatography - mass spectrometry (Table 2). The major components in the leaf oils from 2008 were cyclocolorenone $(23.8 \%$ and $27.5 \%), \alpha$-selinene $(21.2 \%$ and $15.9 \%)$, $\beta$-selinene (8.7\% and 14.8\%), and limonene (8.3\% and 8.1\%). The 2008 leaf oils were dominated by sesquiterpenoids $(79.8 \%$ and $82.3 \%)$. Although qualitatively similar, there were some important differences in the leaf oils from 2009: Sesquiterpenoid concentrations were lower (53.6\% and 68.9\%) with correspondingly increased monoterpenoids (45.9\% and 32.3\%) in 2009; neither $\alpha$-selinene nor $\beta$-selinene were detected in the 2009 leaf oils; there were large concentrations of trans-muurola-4(14),5-diene $(9.5 \%$ and $16.8 \%)$, which were not detected in 2008 , and large concentrations of $\beta$-cadinene (13.3\% and $11.1 \%$ ), which was seen in only one tree from 2008 in small $(0.2 \%)$ quantity. Other major components in the 2009 leaf oils were cyclocolorenone $(14.5 \%$ and $15.6 \%)$, limonene (21.3\% and $12.2 \%$ ), and $\alpha$-pinene (6.9\% and $8.6 \%)$.

Cyclocolorenone has been observed in several species of Asteraceae. The compound was found to be a major component of the essential oils of Solidago gigantea (Asteraceae) $(32.8 \%)[12,13]$, Solidago canadensis (Asteraceae) (38\%) [14], as well as Drimys braziliensis (Winteraceae) (18.2\%) [15]. The compound has also been found in the essential oils of Acritopappus confertus (Asteraceae) [16] and Vernonia brasiliana (Asteraceae) [17], as well as Ledum palustre (Ericaceae) [18] and Eugenia copacabanensis (Myrtaceae) [19].

Several Asteraceae species have been shown to be rich in $\alpha$-selinene, including Baccharis crispa, Baccharis milleflora [20], and Tridax procumbens [21]. $\beta$-Selinene has been observed in B. milleflora [20] and Encelia farinosa [22]. The leaf oils of Heterothalamus alienus (Asteraceae) from Argentina [23], Tagetes minuta (Asteraceae) from Kenya [24], Blumea perrottetiana (Asteraceae) from Nigeria [25], and Clibadium leiocarpum from Costa Rica [26] have all shown trans-muurola-4(15),5-diene in their compositions.

Comparison of the leaf oils from M. guatemalensis with those from other Montanoa species shows little similarity in composition. The major components in the leaf oil from M. grandiflora from Mexico were $\alpha$-pinene $(4.3 \%), \beta$-phellandrene $(4.2 \%)$, limonene $(2.4 \%)$, citronellal $(2.8 \%)$, and guayacol (2.0\%) [27], while M. tomentosa leaf oil from Mexico was dominated by bornyl acetate (26.3\%), (E)-caryophyllene (12.5\%), $\beta$-cubebene (24.0\%), limonene (4.9\%), and borneol (4.1\%) [28]. Headspace analysis of $M$. tomentosa leaves showed a predominance of monoterpenes, $\alpha$-pinene (15.9\%), $\alpha$-thujene (10.4\%), santolina triene (4.6\%), sabinene (39.5\%), limonene (3.7\%), and $\gamma$-terpinene $(5.1 \%$ ) [29], but volatiles from the glandular trichomes of $M$. tomentosa were dominated by the sesquiterpenoids valencene $(25.3 \%-45.0 \%)$ and $\beta$-eudesmol $(27.2 \%-56.1 \%)$ [30].

The leaf oils of $M$. guatemalensis were screened for antibacterial activity against Staphylococcus aureus, Bacillus cereus, and Escherichia coli, but showed only marginal activity against $B$. cereus (Table 3). The oils were also screened for in vitro cytotoxic activity against MDA-MB-231 human mammary adenocarcinoma and Hs578T human mammary ductal carcinoma cells. The oils did show selective cytotoxicity to MDA-MB-231 cells over Hs578T cells (Table 3). A previous report indicated the leaf essential oil of Montanoa ovalifolia from Colombia (composition not reported) had shown marginal cytotoxic activity to Vero and HeLa cells, but no activity against HepG2 or Jurkat cells [31]. 


\section{Conclusions}

This is the first analysis of the volatiles from Montanoa guatemalensis. The leaf oil, rich in cyclocolorenone, $\alpha$-selinene, and $\beta$-selinene, showed selective in vitro cytotoxic activity to MDA-MB-231 cells. It is not clear, however, what components are responsible for the cytotoxicity, but the plant may be a good source of cyclocolorenone. Although this work presents preliminary results, it should serve as a template for further experimentation on the leaf oil compositions of M. guatemalensis, seasonal, individual, and year-to-year variations.

\section{Acknowledgments}

We are very grateful to the Monteverde Cloud Forest Preserve and the Tropical Science Center for granting us permission to collect plant materials under a cooperative rights agreement and to the Commission for the Development of Biodiversity of Costa Rica's Ministry of the Environment, Energy, and Telecommunications for Research Permit R-001-2006-OT-CONAGEBIO. We are grateful to Maynor Vargas Arguedas for permission to collect plant materials on the property of Hotel El Bosque, Monteverde. We thank William A. Haber for plant identification, Brenda S. Wright and Debra M. Moriarity for technical assistance with the cytotoxicity screening, and Bernhard Vogler for technical assistance with the GC-MS instrumentation.

\section{Author Contributions}

William N. Setzer conceived and designed the project; Victoria D. Flatt and Carlos R. Campos collected and hydrodistilled the essential oils; Maria P. Kraemer and Brittany A. Bailey performed the bioactivity assays; Prabodh Satyal and William N. Setzer analyzed the data; William N. Setzer wrote the manuscript.

\section{Conflicts of Interest}

The authors declare no conflict of interest.

\section{References}

1. Haber, W.A.; Zuchowski, W.; Bello, E. An Introduction to Cloud Forest Trees: Monteverde, Costa Rica, 2nd ed.; Mountain Gem Publications: Monteverde, Costa Rica, 2000.

2. Piper, J.K. Colonization of tubú (Montanoa guatemalensis, Asteraceae) windbreaks by woody species. Biotropica 2006, 38, 122-126.

3. Seaman, F.C.; Malcolm, A.J.; Fischer, N.H. Sesquiterpene lactones of Montanoa guatemalensis and Montanoa tomentosa subsp. xanthiifolia. Phytochemistry 1985, 24, 2003-2005.

4. NIST (National Institute of Standards and Technology). Mass Spectral Library (NIST/EPA/NIH, V. 2.0g); The NIST Mass Spectrometry Data Center: Gaithersburg, MD, USA, 2011.

5. Adams, R.P. Identification of Essential Oil Components by Gas Chromatography/Mass Spectrometry, 4th ed.; Allured Publishing Corp.: Carol Stream, IL, USA, 2007. 
6. Satyal, P. Development of GC-MS Database for Essential Oil Analysis, Adulteration Detection in Commercial Essential Oil Samples, and Discovery of Biologically Active Novel Chemotypes in Essential Oils. Ph.D. Thesis, University of Alabama in Huntsville, Huntsville, AL, USA, November, 2015.

7. Sahm, D.H.; Washington, J.A. Antibacterial susceptibility tests: Dilution methods. In Manual of Clinical Microbiology, 5th ed.; Balows, A., Hausler, W.J., Herrmann, K.L., Isenberg, H.D., Shamody H.J., Eds.; American Society for Microbiology: Washington, DC, USA, 1991.

8. Cailleau, R.; Young, R.; Olive, M.; Reeves, W.J. Breast tumor cell lines from pleural effusions. J. Natl. Cancer Inst. 1974, 53, 661-674.

9. Hackett, A.J.; Smith, H.S.; Springer, E.L.; Owenms, R.B.; Nelson-Rees, W.A.; Riggs, J.L.; Gardner, M.B. Two syngeneic cell lines from human breast tissue: The aneuploid mammary epithelial (Hs578T) and the diploid myoepithelial (Hs578Bst) cell lines. J. Natl. Cancer Inst. 1977, 58, 1795-1806.

10. Setzer, W.N.; Setzer, M.C.; Hopper, A.L.; Moriarity, D.M.; Lehrman, G.K.; Niekamp, K.L.; Morcomb, S.M.; Bates, R.B.; McClure, K.J.; Stessman, C.C.; et al. The cytotoxic activity of a Salacia liana species from Monteverde, Costa Rica, is due to a high concentration of tingenone. Planta Med. 1998, 64, 583.

11. Ferrari, M.; Fornasiero, M.C.; Isetta, A.M. MTT colorimetric assay for testing macrophage cytotoxic activity in vitro. J. Immunol. Meth. 1990, 131, 165-172.

12. Kalemba, D.; Marschall, H.; Bradesi, P. Constituents of the essential oil of Solidago gigantea Ait. (giant goldenrod). Flavour Fragr. J. 2001, 16, 19-26.

13. Kalemba, D.; Thiem, B. Constituents of the essential oils of four micropropagated Solidago species. Flavour Fragr. J. 2004, 19, 40-43.

14. Schmidt, C.O.; Bouwmeester, H.J.; Bülow, N.; König, W.A. Isolation, characterization, and mechanistic studies of (-)- $\alpha$-gurjunene synthase from Solidago canadensis. Arch. Biochem. Biophys. 1999, 364, 167-177.

15. Gomes, M.R.F.; Schuh, R.S.; Jacques, A.L.B.; Augustin, O.A.; Bordignon, A.L.; Dias, D.O.; Kelmann, R.G.; Koester, L.S.; Gehring, M.P.; Morrone, F.B.; et al. Citotoxic activity evaluation of essential oils and nanoemulsions of Drimys angustifolia and D. braziliensis on human glioblastoma (U-138 MG) and human bladder carcinoma (T24) cell lines in vitro. Rev. Bras. Farmacog. 2013, 23, 259-267.

16. Lima, M.A.S.; Barros, M.C.P.; Pinheiro, S.M.; do Nascimento, R.F.; Matos, F.J.A.; Silveira, E.R. Volatile compositions of two Asteraceae from the northeast of Brazil: Ageratum conyzoides and Acritopappus confertus (Eupatorieae). Flavour Fragr. J. 2005, 20, 559-561.

17. Martins, M.M.; de Morais, S.A.L.; de Oliveira, A.; do Nascimento, E.A.; de Aquino, F.J.T.; Chang, R.; Borges, M.S.; de Melo, G.B.; da Silva, C.V.; Machado, F.C. Chemical composition, antimicrobial and antiprotozoal activity of essential oils from Vernonia brasiliana (Less) Druce (Asteraceae). J. Essent. Oil Bear. Plants 2015, 18, 561-569.

18. Gretšušnikova, T.; Järvan, K.; Orav, A.; Koel, M. Comparative analysis of the composition of the essential oil from the shoots, leaves and stems the wild Ledum palustre L. from Estonia. Proc. Chem. 2010, 2, 168-173. 
19. Nakamura, M.J.; Monteiro, S.S.; Bizarri, C.H.B.; Siani, A.C.; Ramos, M.F.S. Essential oils of four Myrtaceae species from the Brazilian southeast. Biochem. Systemat. Ecol. 2010, 38, 1170-1175.

20. Simões-Pires, C.A.; Debenedetti, S.; Spegazzini, E.; Mentz, L.A.; Matzenbacher, N.I.; Limberger, R.P.; Henriques, A.T. Investigation of the essential oil from eight species of Baccharis belonging to sect. Caulopterae (Asteraceae, Astereae): A taxonomic approach. Plant Syst. Evol. 2005, 253, 23-32.

21. Joshi, R.K.; Badakar, V. Chemical composition and in vitro antimicrobial activity of the essential oil of the flowers of Tridax procumbens. Nat. Prod. Commun. 2012, 7, 941-942.

22. Wright, C.; Chhetri, B.K.; Setzer, W.N. Chemical composition and phytotoxicity of the essential oil of Encelia farinosa growing in the Sonoran Desert. Am. J. Essent. Oils Nat. Prod. 2013, 1, $18-22$.

23. Ruffinengo, S.R.; Maggi, M.; Fuselli, S.; Floris, I.; Clemente, G.; Firpo, N.H.; Bailac, P.N.; Ponzi, M.I. Laboratory evaluation of Heterothalamus alienus essential oil against different pests of Apis mellifera. J. Essent. Oil Res. 2006, 18, 704-707.

24. Onyambu, G.K.; Maranga, R.; Ndungu, M.; Mkoji, G.M.; Kareru, P.G.; Wanjoya, A. GC-MS analysis of pesticidal essential oils from four Kenyan plants. Afr. J. Biotechnol. 2015, 14, $1158-1166$.

25. Owolabi, M.S.; Lajide, L.; Villanueva, H.E.; Setzer, W.N. Essential oil composition and insecticidal activity of Blumea perrottentiana growing in southwestern Nigeria. Nat. Prod. Commun. 2010, 5, 1135-1138.

26. Washington, V.D.; Agius, B.R.; Palazzo, M.C.; Haber, W.A.; Setzer, W.N. Chemical composition of the leaf essential oil of Clibadium leiocarpum from Monteverde, Costa Rica. Am. J. Essent. Oils Nat. Prod. 2013, 1, 43-45.

27. Pérez-Amador, M.C.; Muñoz, V.; Noyola, A.; García-Jiménez, F. Essential oil and phototoxic compounds in Clibadium surinamense L. and Montanoa grandiflora D.C. (Asteraceae). Phyton 2006, 75, 145-150.

28. Compadre, C.M.; Hussain, R.A.; Leon, I.; Enríquez, R.G. Volatile constituents of Montanoa tomentosa and Lippia graveolens. Planta Med. 1987, 53, 495-496.

29. Robles-Zepeda, R.E.; Molina-Torres, J.; Lozoya-Gloria, E.; López, M.G. Volatile organic compounds of leaves and flowers of Montanoa tomentosa. Flavour Fragr. J. 2006, 21, 225-227.

30. Robles-Zepeda, R.E.; Lozoya-Gloria, E.; López, M.G.; Villarreal, M.L.; Ramírez-Chávez, E.; Molina-Torres, J. Montanoa tomentosa glandular trichomes containing kaurenoic acids chemical profile and distribution. Fitoterapia 2009, 80, 12-17.

31. Zapata, B.; Betancur-Galvis, L.; Duran, C.; Stashenko, E. Cytotoxic activity of Asteraceae and Verbenaceae family essential oils. J. Essent. Oil Res. 2014, 26, 50-57.

(C) 2015 by the authors; licensee MDPI, Basel, Switzerland. This article is an open access article distributed under the terms and conditions of the Creative Commons Attribution license (http://creativecommons.org/licenses/by/4.0/). 